\title{
3. Choice of Antihypertensive Agents in Hemodynamie Aspects to Match Patho- physiology and Pharmacology in Essential Hypertension
}

\author{
Hisaichiro TSUKIYAMA
}

Department of Cardiovascular Diseases, Kanagawa Cancer Center, Yokohama

To prevent complications with elevated blood pressure, it is advantageous to select antihypertensive agents to restore disturbed hemodynamics to normal without any adverse effects. We review the hemodynamic effects of various antihypertensive agents, and the choice of them is discussed.

Therapeutic use of $\beta$-blocking agents with different ancillary properties has been well established in hypertension, but treatment with these drugs was associated with a wide spectrum of hemodynamic responses $(1-9,12)$ (Figure 1). Pindolol and bunitrolol, non-selective $\beta$-blocking agents with moderate ISA (intrinsic sympathomimetic activity), reduced calculated peripheral vascular resistance with no change or slight increase in cardiac pump function. Combined vascular $\alpha$ receptor blocking activity and ISA on vascular

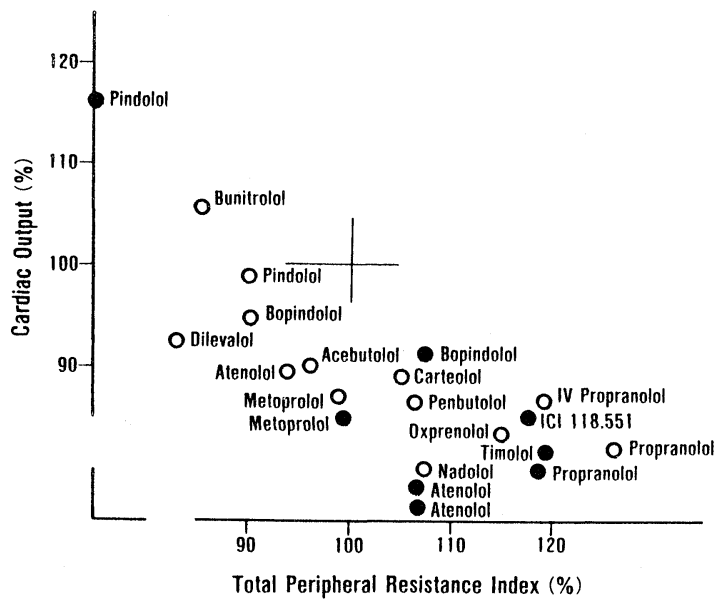

$\beta_{2}$-receptor may counteract $\beta_{2}$-blocking action with a resultant decrease in peripheral resistance as shown in labetalol, dilevalol and celiprolol. Atenolol and metoprolol, $\beta_{1}$-selective $\beta$-blocking agents with no ISA, reduced cardiac output, but did not increase definitely peripheral resistance. Nonselective $\beta$-blocking agents with no or weak ISA, such as propranolol or oxprenolol, induced reduction in cardiac output and a slight increase in peripheral resistance. These beta-blocking agents will not only lower blood pressure, but will restore other pathophysiological disturbances, e.g. elevated cardiac output and heart rate, in young hypertensive patients. Cardiovascular findings in the elderly hypertensive are low cardiac output and high peripheral resistance. In these cases, use of $\beta$ blocking agents with moderate ISA and/or $\alpha$ -

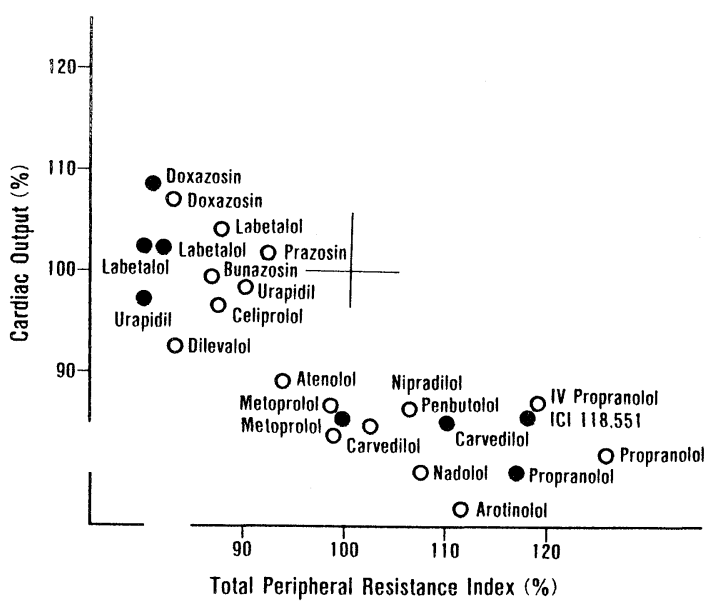

Fig. 1. The mode of hemodynamic responses to $\beta$-blockade (left panel) and $\alpha, \beta$-blockage (right panel) is illustrated. Open circles show the changes of the cardiac output and total peripheral resistance index in our studies, and filled circles show those reported previously: pindolol (van den Meiracker AH et al., 1987 (1)), labetalol (Edwards RC et al., 1976 (2); Koch G, 1979 (3)), bopindolol (van den Meiracker AH et al., 1987 (1)), metoprolol (Sannerstedt R, 1975 (4)), atenolol (Amery A et al., 1976 (5); Jensen HE et al., 1976 (6)), timolol (Aronow WS et al., 1976 (7); Hansson L et al., 1974 (8)), ICI 118,551 ( $\beta 2_{2}$-selective $\beta$-blocking agent) (Dählof B et al., 1983 (9)), doxazosin (Lund-Johansen $\mathrm{P}$ et al., 1986 (10)). urapidil (Trimarco B et al., 1986 (11)) and carvedilol (Dupont AG et al., 1986 (12)). The cross indicates the pretreatment values. 
blocking activity might be considered. As atenolol and acebutolol did not deteriorate cardiac pump function and reduced blood pressure effectively in the elderly hypertensive patients with low cardiac output in our study, small doses of $\beta_{1}$-selective $\beta$-blocking agents may be generally well tolerated in them.

Short-term treatment with diuretics reduced plasma volume and cardiac output, and these effects were reported to be restored to the pretreatment levels during long-term treatment, while the reduction in blood pressure maintained (Conway $\mathrm{J}$ et al., 1960) (13). However, cardiac output and plasma volume continued to be reduced after prolonged therapy in other reports (Shah S et al., 1978 (14); Huang CM et al., 1979) (15) (Figure 2). These findings coincided with earlier report in which a loss of extracellular fluid volume was maintained as long

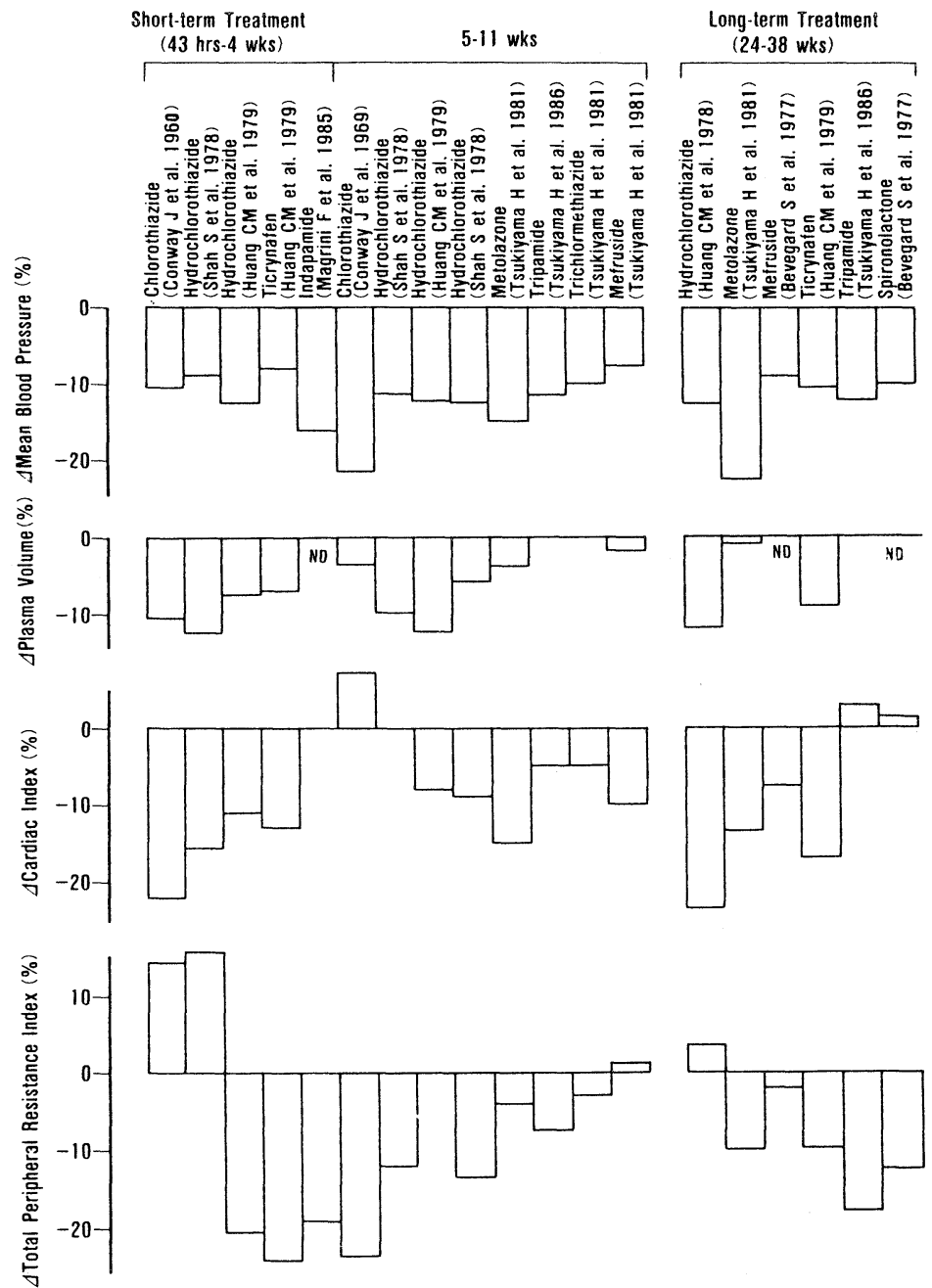

Fig. 2. Hemodynamic effects of short- and long-term treatment with diuretics: chlorothiazide (Conway J et al., 1969 (13)), hydrochlorothiazide (Shah S et al., 1978 (14); Huang CM et al., 1979 (15)), ticrynafen (Huang CM et al., 1979 (15)), indapamide (Magrini F et al., 1985 (16)), metolazone (Tsukiyama $\mathrm{H}$ et al., 1981 (17)), tripamide (Tsukiyama $\mathrm{H}$ et al., 1986 (18)), trichlormethiazide (Tsukiyama $\mathrm{H}$ et al., 1981 (17)), mefruside (Tsukiyama $\mathrm{H}$ et al., 1981 (17); Bevegard $\mathrm{S}$ et al., 1977 (19)) and spironolactone (Bevegard S et al., 1977 (20)). 
as the thiazide was taken (Wilson IM et al., 1961) (21).

Diuretics can be used as first step agents in lowrenin form of essential hypertension, elderly hypertension, volume-dependent hypertension with renal parenchimal diseases and steroid-dependent form of hypertension, and can be combined with other antihypertensive agents. Since both $\beta$-blocking agents and diuretics suppress cardiac pump function, their combined therapy should be begun to use in small doses to minimize side effects, and more data are needed to define its risk in patients with impaired left ventricular function.

Calcium antagonists and angiotensin converting enzyme (ACE) inhibitors are becoming increasing used for treatment of hypertension. Acute administration of nifedipine produced a modest and acute reduction of blood pressure with increased heart rate, increased cardiac output and reduced peripheral resistance (Guazzi MD et al., 1983) (22). This efficacy of lowering blood pressure in hypertensive emergencies has been confirmed. Verapamil and diltiazem did not seem to cause these acute reflex stimulation in our study. During long-term treatment with these calcium antagonists, blood pressure was reduced and peripheral resistance also fell, and nifedipine-induced increase in heart rate and cardiac output diminished.

In the clinical reports of ACE inhibitor (captopril, enalapril, alacepril and altiopril), their acute and chronic administration reduced blood pressure and peripheral resistance without an increase in heart rate and cardiac output in hypertensive patients (Daly $\mathrm{P}$ et al., 1984 (23); Wikstrand J et al., 1984 (24); Cody RJ et al., 1978 (25); Tsukiyama H et al., 1985 (26)). No definite difference was observed among them. These calcium antagonists and ACE inhibitors are suitable for patients with high peripheral resistance (e.g. the middle-aged to the elderly patients), as antihypertensive responses to calcium antagonists was greater in older patients and an ACE inhibitor was reported to be equally effective in lowering the high blood pressure of the young and the old.

Recent intervention trials reveal that it may be dangerous to lower blood pressure too much, especially in patients with coronary diseases. The mortality or morbidity of ischemic heart diseases was reported to be lowest at the small range of treated diastolic blood pressure; Cruickshank JM et al. (1987), 85-90 mmHg (27); Samuelsson O et al. (1987), 86-89 mmHg (28); Waller PC et al. (1987), 91-98 mmHg (29); Bulpitt CJ et al. (1988), 85-90 mmHg (30); Stewart IMcDG (1979), 100-109 mmHg (Korotkov IV phase) (31). This death rate rose with treated diastolic blood pressure on the either side of these ranges. These results suggest that the beneficial effects of antihypertensive treatment in term of protection against hypertensive organ damage may be obtained both by the choice of adequate antihypertensive agents and avoidance of excessive reduction in blood pressure.

\section{REFERENCES}

1) van den Meiracker AH, Man'in't Veld, Schalekamp MADH: Acute and long-term haemodynamic effects of pindolol. In: The position of bopindolol. A new $\beta$-blocker (ed by van Zwieten PA). Royal Society of Medicine Services, London, 1987, p35-41.

2) Edwards RC, Raftery EB: Haemodynamic effects of long-term oral labetalol. Br J Clin Pharmacol 3 (Suppl 3): 733-736, 1976.

3) Koch G: Haemodynamic adaptation at rest and during exercise to a long-term antihypertensive treatment with combined alpha- and beta-adrenoceptor blockade by labetalol. Br Heart J 41: 192-198, 1979.

4) Sannerstedt R: Haemodynamic effects od adrenergic $\beta$-receptor-blocking agents in arterial hypertension. In: Pathophysilogy and management of arterial hypertension (ed by Berglund G, Hansson L and Werko L). Astra, Molndal, 1975, p194-200.

5) Amery A, Billiet L, Boel A, Fagard R, Reybrouck T, Williams J: Mechanism of hypotensive effective during $\beta$-adrenergic blockade in hypertensive patients. Hemodynamic and renin response to a new cardioselective agent; Tenormin or ICI 66,0082. Am Heart J 91: 634-642, 1976.

6) Jensen HE, Rasmussen K, Mosbaek N: Clinical and haemodynamic study of atenolol (Tenormin) in essential hypertension. Clin Sci Mol Med 5 (Suppl 3): 525-526, 1976.

7) Aronow WS, Ferlinz J, Del Vicario M, Moorthy K, King J, Kassidy J: Effects of timolol versus propranolol on hypertension and hemodynamics. Circulation 54: 47-51, 1976.

8) Hansson L, Zweifler AJ, Julius S, Hunyor S: Hemodynamic effects of acute and prolonged $\beta$ adrenergic blockade in essential hypertension. Acta Med Scand 196: 27-34, 1974.

9) Dählof B, Andrén L, Svensson A, Hansson L: Antihypertensive mechanism of beta-adrenoceptor antagonism - The role of beta ${ }_{2}$-blockade. J Hypertension 
1 (Suppl 2): 112-115, 1983.

10) Lund-Johansen P, Omvik P, Haugland H: Acute and chronic haemodynamic effects of doxazosin in hypertension at rest and during exercise. Br J Clin Pharmacol 21 (Suppl): 45-54, 1986.

11) Trimarco B, Ricciardelli B, Cuocolo A, de Luca N, Volpe M, Veniero A, Condorelli M: Effects of one year of antihypertensive treatment with urapidil on left ventricular haemodynamics and anatomy. In: Treatment of hypertension with urapidil. Preclinical and clinical update (ed by Amery A). Royal Society of Medicine Services, London, 1986, p101-110.

12) Dupont $A G$, Van der Niepen $P$, Taeymans $Y$, Ingels M, Piepsz A, Bossuyt AM, Block P, Six RO, Jonckheer $\mathrm{MH}$, Vanhaelst L: Effect of carvedilol on ambulatory blood pressure, renal hemodynamics, and cardiac function in essential hypertension. J Cardiovasc Pharmacol 10 (Suppl 11): 130-136, 1987.

13) Conway J, Lauwers P: Hemodynamic and hypotensive effects of long-term therapy with chlorothiazide. Circulation 21: 21-27, 1960.

14) Shah S, Khatri I, Freis ED: Mechanism of antihypertensive effects of thiazide diuretics. Am Heart J 95: 611-618, 1978.

15) Haung CM, Chock D, del Greco F, Armstrong M, Croc J, Quintanilla A: Antihypertensive and hemodynamic effects of ticrynafen compared with hydrochlorothiazide. Nephr 23 (Suppl 1): 51-56, 1979.

16) Magrini F, Buzzetti G, De Giovanni F, Cerati D, Macchi G, Mondadori C: Systemic and pulmonary hemodynamic effects of indapamide in patients with mild arterial hypertension. J Cardiovasc Pharmacol 7: 281-285, 1985.

17) Tsukiyama H, Otsuka K, Yamamoto $Y$, Tanaka $T$, Higuma K, Kitamura Y: The effects of short- and longterm treatment of metolazone on systemic blood pressure, cardiac output, cardiopulmonary blood volume, and cardiac output/cardiopulmonary blood volume in essential hypertension (in Japanese). Jpn J Clin Pharmacol Ther 12: 311-322, 1981.

18) Tsukiyama $\mathrm{H}$, Otsuka $\mathrm{K}$ : Effects of tripamide and metolazone on hemodynamics in patients with essential hypertension (in Japanese). Jpn J Clin Pharmacol Ther 17: 33-34, 1986.

19) Bevegard S, Castenfors J, Danielson M: Haemodynamic effects of four months' mefruside therapy in hypertensive patients. Acta Med Scand 201: 93-97, 1977.

20) Bevegard S, Castenfors J, Danielson M: The effects of four months' treatment with spironolactone on systemic blood pressure, cardiac output and plasma renin activity in hypertensive patients. Acta Med Scand 202: 373-377, 1977.

21) Wilson IM, Freis ED: Relationship between plasma and extracellular fluid volume depletion and the antihypertensive effect of chlorothiazide. Circulation 20: 1028-1036, 1961.

22) Guazzi MD, Polese A, Fiorentini C, Bartorelli A, Moruzzi P: Treatment of hypertension with calcium antagonists. Review. Hypertension 5 (Suppl II): 85-90, 1983.

23) Daly P, Rouleau J-L, Consineau D, Burgess JH: Acute effects of captopril on the coronary circulation of patients with hypertension and angina. Am J Med 76(5B): 111-115, 1984.

24) Wikstrand J, Herlitz H, Berglund G: Acute and subacute haemodynamic effects of enalapril. Scand $\mathbf{J}$ Uro Nephr Suppl 79: 81-85, 1984.

25) Cody RJ Jr, Trazi RC, Bravo EL, Fouad FM: Haemodynamics of orally-active enzyme inhibitor (SQ 14225 ) in hypertensive patients. Clin Sci Mol Med 55: 453-459, 1987.

26) Tsukiyama $H$, Otsuka $K$, Horii $M$, Takasaki I, Ise $T$, Nakamura Y, Takizawa S: Effects of alacepril and enalapril on hemodynamics in patients with essential hypertension (in Japanese). Jpn Pharmacol Ther 13: 5195-5204, 1985.

27) Cruickshank JM, Thorp JM, Zacharias FJ: Benefits and potential harm of lowering high blood pressure. Lancet I: $581-584,1987$.

28) Samuelsson $O$, Wilhelmsen $L$, Andersson $O K$, Pennert $\mathrm{K}$, Berglund G: Cardiovascular morbidity in relation to change in blood pressure and serum cholesterol levels in treated hypertension. JAMA 258: 1768-1776.

29) Waller PC, Isles CG, Lever AF, Murray GD, McInnes CT: Is there a level of treated distolic blood pressure below which mortality from myocardial infarction increases? (Abstr) J Hypertension 5: 764, 1987.

30) Bulpitt CJ, Beevers DG, Butler A, Coles EC, Fletcher AE, Hunt D, Munro-Faure AD, Newson R, O'Riordan PW, Perie JC, Rajagopalan B, Rylance PW, Twallin G, Webster J, Dollery CT: Treated blood pressure, rather than pretreatment, predicts survival in hypertensive patients. A report from the DHSS Hypertensive Care Computing Project (DHCCP). J Hypertension 6: 627-632, 1988 .

31) Stewart I McDG: Relation of reduction in pressure to first myocardial in patients receiving treatment for severe hypertension. Lancet I: 861-869, 1979. 